\title{
NILAI-NILAI KEHIDUPAN SOSIAL DALAM PERMAINAN TRADISIONAL ANAK DI DAERAH ISTIMEWA YOGYAKARTA PADA ERA GLOBALISASI
}

\author{
Oleh \\ Mujinem)*
}

\begin{abstract}
Abstrak
Globalisasi seperti sekarang ini, di mana teknologi maju pesat, ternyata telah mengubah perilaku kehidupan sosial di masyarakat, khususnya anak. Permainan tradisional yang dulu melekat pada dunia anak di daerah pedesaan, sekarang sangat sulit ditemukan apalagi di daerah perkotaan. Sebagai pengganti, anak-anak bermain play station, game boy, tamiya, dan lain-lain pada saat ini. Pada hal permainan tradisional anak, seperti Jamuran, Mul-mulan, Jeg-jegan banyak mengandung nilai-nilai kehidupan sosial yang mencerminkan kearifan budaya suatu daerah. Adapun nilai-nilai permainan tradisional anak tersebut adalah adanya persamaan status, kebersamaan, ketaatan terhadap aturan, berpikir strategis dan kreatif, kecerdasan, kompetisi, kepekaan sosial, tanggung jawab, sikap lapang dada, dorongan untuk berprestasi, dan belajar untuk menyesuaikan diri.

Untuk melestarikan permainan tradisional anak yang nyaris hilang ditelan perkembangan zaman, perlu adanya upaya dalam bentuk statis (identifikasi dan pendokumentasian) maupun dinamis (mengajarkan untuk dimainkan). Pengajaran tentang permainan tradisional ini perlu kepedulian dari berbagai pihak yaitu keluarga, sekolah, maupun masyarakat. Di era globalisasi ini permainan tradisional anak tetap masih relevan untuk dilestarikan, karena bermanfaat sebagai tempat sosialisasi nilai-nilai luhur dalam kehidupan sosial.
\end{abstract}

\section{Pendahuluan}

Pada dasarnya bermain adalah panggilan manusiawi, setiap manusia mengalami proses bermain. Bahkan manusia disebut sebagai makhluk bermain (homoludens). Walaupun tergolong makhluk bermain, ternyata manusia bukanlah makhluk yang mainmain. Buktinya, dalam permainan pasti ada unsur yang serius. Mendengar kata bermain sering terlintas di dalam pikiran adanya nostalgia di masa anak-anak, sebab masa anakanak adalah masa permainan. Hamzuri dan Tiarma Rita Siregar sebagaimana dikutip oleh Dani Wardani (2007) mengatakan bahwa permainan tradisional memiliki ragam bentuk dan variasi yang sangat banyak. Setidaknya ada 750 macam permainan tradisional di Indonesia dan masih banyak yang belum terinventarisasi. Hal ini mengidentifikasikan bahwa permainan tradisional Indonesia sangat melimpah. Dari sekian banyak jenis permainan tradisonal tersebut berhasil dideskripsikan sebanyak 40 jenis yang terdapat di Daerah Istimewa Yogyakarta (DIY). 
Namun sayang, permainan tradisional tersebut sekarang ini keberadaannya sangat sulit ditelusuri dan dilacak, atau bisa dikatakan terancam punah. Permainan tradisional di DIY seperti Jamuran, Mul-mulan,Jjeg-jegan, dan lain-lain secara perlahan-lahan sudah digantikan posisinya oleh berbagai perangkat permainan dalam komputer. Sekarang ini, play station, game boy, sudah menjadi "makanan" sehari-hari anak-anak Indonesia terutama yang tinggal di kota-kota besar. Menjamurnya penyewaan play station di kotakota, hingga ke desa-desa membuat anak-anak di desa pun mulai melirik permainan tersebut. Anak-anak lebih cenderung bermain dalam permainan yang terkesan instan. Kemajuan teknologi membawa banyak kemudahan bagi anak-anak. Permainanpermainan baru dalam bentuk game komputer diciptakan. Permainan seperti itu menjadi semakin kaya sensasi, mengasyikan dan penuh fantasi. Tidak mengherankan, permainan tradisional mulai ditinggalkan. Permainan tradisional digantikan dengan permainan produk teknologi. Game-game menjadi lebih praktis, karena tidak memerlukan tanah lapang dan banyak teman. Cukup sendirian di depan layar pun seseorang bisa terjun dalam permainan yang mengasyikkan. Permasalahannya adalah apakah permainan tradisional anak itu sama sekali sudah tidak bermanfaat bagi kehidupan sosial?

Pada kesempatan ini tidak semua permainan tradisional akan dibahas dan hanya tiga permainan yang dianggap populer di DIY yaitu Jamuran, Mul-mulan, dan Jegjegan. Permasalahan yang akan dibahas di sini adalah nilai-nilai sosial apa saja yang ada dalam permainan tradisional anak, kemudian nilai-nilai yang ada dalam pemainan tradisional anak tersebut apakah dibiarkan hilang begitu saja? Jika dipandang dari unsur budaya masih relevankah permainan tradsional di era globalisasi ini tetap dilestarikan, jika masih relevan bagaimana cara-cara melestarikan permainan tersebut, dan sebetulnya apa manfaat permainan tradisional itu dilestarikan.

\section{Pengertian Nilai}

Nilai adalah sifat atau kualitas yang melekat pada suatu objek, bukan objek itu sendiri. Suatu itu mengandung nilai artinya ada sifat atau kualitas yang melekat pada suatu itu. Misalnya, perbuatan itu bermoral, pemandangan itu indah. Susila dan indah adalah sifat yang melekat pada tindakan dan pemandangan (Rukiyati, 2008). 
Kosasih Djahiri (1980) menyebutkan nilai adalah keyakinan, kepercayaan, norma atau kepatuhan-kepatuhan yang dianut oleh seseorang ataupun kelompok masyarakat tentang sesuatu. Sementara itu menurut Fraenkel sebagaimana dikemukakan oleh Husein Achmad (1982) nilai menggambarkan suatu penghargaan atau semangat yang diberikan seseorang atas pengalaman-pengalamannya. Koentjaraningrat (1979) mengemukakan bahwa suatu sistem nilai budaya terdiri dari konsepsi-konsepsi yang hidup dalam alam pikiran sebagian besar warga masyarakat mengenai hal-hal yang harus mereka anggap amat bernilai dalam hidup. Dengan demikian nilai itu sebenarnya suatu kenyataan yang tersembunyi di balik kenyataan-kenyataan lainnya. Adanya nilai itu karena ada kenyataan-kenyataan lain sebagai pembawa nilai. Nilai mengandung cita-cita, harapanharapan, dan keharusan. Bagi manusia nilai dipakai dan diperlukan untuk menjadi landasan alasan, motivasi dalam bersikap, bertingkah laku dan perbuatannya.

Segala sesuatu itu mengandung nilai, hanya derajad nilai itu positif atau negatif. Nilai-nilai apa yang terkandung di dalam sesuatu itu masih harus ditentukan kemudian. Ada usaha telah dilakukan untuk mengklasifikasikan nilai. Walter G. Everet sebagaimana dikutip oleh Rukiyati (2008) menggolongkan nilai-nilai manusiawi menjadi delapan kelompok, yaitu:

1. Nilai ekonomis yaitu ditunjukkan oleh harga pasar dan meliputi semua benda itu yang dapat dibeli. Misalnnya, emas atau logam mulia mempunyai nilai ekonomis dibanding dengan seng.

2. Nilai-nilai kejasmanian yaitu mengacu pada kesehatan, efisiensi, dan keindahan badan. Misalnya, kebugaran, kesehatan, kemulusan tubuh, dan kebersihan.

3. Nilai-nilai hiburan yaitu nilai-nilai permainan di waktu senggang yang dapat menyumbang pada pengayaan kehidupan. Misalnya, kenikmatan rekreasi, keharmonisan musik, keselarasan nada.

4. Nilai-nilai sosial yaitu berasal dari pelbagai bentuk perkumpulan manusia. Misalnya, kerukunan, persahabatan, persaudaraan, kesejahteraan, keadilan, kerakyatan, dan persatuan.

5. Nilai-nilai watak yaitu keseluruhan dari keutuhan kepribadian dan sosial yang diinginkan. Misalnya, kejujuran, kesederhanaan, dan kesetiaan. 
6. Nilai-nilai estetis yaitu nilai-nilai keindahan dalam alam dan karya seni. Misalnya, keindahan, keselarasan, keseimbangan, dan keserasian.

7. Nilai-nilai intelektual yaitu nilai-nilai pengetahuan dan pengejaran kebenaran. Misalnya, kecerdasan, ketekunan, kebenaran, dan kepastian.

8. Nilai-nilai keagamaan yaitu nilai-nilai yang ada dalam agama. Misalnya, kesucian, keagungan Tuhan, keesaan Tuhan, dan keibadahan.

Sementara itu menurut Notonagoro nilai dibagi menjadi tiga yaitu:

1. Nilai material yaitu segala sesuatu yang berguna bagi jasmani manusia. Misalnya, kebutuhan makan, minum, sandang, papan, dan kesehatan.

2. Nilai vital yaitu segala sesuatu yang berguna bagi manusia untuk dapat mengadakan kegiatan atau aktivitas. Misalnya, semangat, kemauan, ketekunan, dan kerja keras.

3. Nilai kerohanian yaitu segala sesuatu yang berguna bagi rohani manusia. Nilai kerohanian dibedakan menjadi empat, yaitu: a) nilai kebenaran yang bersumber pada akal (cipta); b) nilai keindahan (nilai estetis) yang bersumber pada unsur rasa; c) nilai kebaikan (nilai moral) yang bersumber pada unsur karsa; d) nilai religius merupakan nilai kerohanian tertinggi dan mutlak. Nilai ini bersumber pada kepercayaan dan keyakinan manusia.

Memperhatikan pengertian-pengertian nilai di atas dapat dikatakan bahwa nilai terdapat dalam suatu tindakan atau tingkah laku manusia yang hidup dalam masyarakat dan setiap tingkah laku manusia pasti mengandung nilai. Oleh karena itu, sekiranya tidak berlebihan jika akan dibahas lebih lanjut mengenai nilai-nilai kehidupan sosial apa yang terkandung dalam permainan tradisional anak.

\section{Jenis Permainan Tradisional Anak}

Dharmamulya (2008) membedakan jenis-jenis permainan tradisional menjadi tiga sesuai dengan kategorisasi menurut pola permainannya yaitu bermain dan bernyanyi dan atau dialog, bermain dan olah pikir, dan bermain dan adu ketangkasan.

\section{A. Bermain dan Bernyanyi dan atau Dialog}

Permainan tradisional dengan pola bermain bernyanyi dan atau dengan dialog adalah pada waktu permainan itu dimainkan diawali atau diselingi dengan nyanyian, 
dialog atau keduanya. Nyanyian dan dialog menjadi inti dari permainan tersebut. Permainan anak dilakukan dengan bernyanyi dengan irama tertentu sambil bertepuk tangan atau dengan gerakan-gerakan fisik tertentu, atau dengan ucapan kata-kata. Pola permainan seperti itu pada umumnya dilakukan secara kelompok.

Salah satu contoh permainan tradisional yang menggunakan media bernyanyi dan berdialog adalah Jamuran. Permainan ini sangat populer di kalangan anak-anak khususnya di DIY. Kata Jamur artinya cendawan, kata Jamuran mendapat akhiran an. Jamur berbentuk bulat, permainan Jamuran pun memfisualisasikan bentuk jamur yang bulat tersebut yaitu membentuk lingkaran. Permainan ini biasanya dilakukan pada sore hari atau malam hari (waktu bulan purnama). Jamuran dapat dilaksanakan di halaman rumah, halaman sekolah, atau di lapangan.

Mengenai jumlah pemain tidak dibatasi, biasanya berkisar antara enam sampai dengan dua belas anak. Sedangkan batasan umur juga tidak mengikat. Anak kecil pun dapat ikut serta meskipun hanya sebagai bawang kothong (pemain pura-pura). Namun idealnya permainan ini diikuti oleh anak yang berumur enam sampai dengan tiga belas tahun. Peserta permainan Jamuran ini dapat dilakukan oleh anak perempuan saja, anak laki-laki saja, atau campuran anak laki-laki dan perempuan.

Permainan Jamuran memerlukan sebidang tanah yang cukup (sebanyak pemain), lagu pengiring yang dinyanyikan oleh semua pemain Jamuran. Lagu Jamuran dinyanyikan satu kali setiap ronde. Oleh karena itu jika bermain sampai sepuluh ronde maka lagunya pun dinyanyikan sebanyak sepuluh kali.

Jalannya permainan dapat dijelaskan sebagai berikut: setelah sekelompok anak (misalnya ada delapan anak) yang berkeinginan bermain Jamuran berkumpul, maka dilakukan undian untuk menentukan siapa menjadi pemain dadi dan siapa menjadi pemain mentas. Siapa yang paling kalah dialah yang dadi. Misalnya yang main A, B, C, D, E, F, G, dan H. Berdasarkan undian $\mathrm{H}$ adalah pemain yang paling kalah, maka $\mathrm{H}$ menjadi pemain dadi. Kemudian A, B, C, D, E, F, G berdiri membentuk lingkaran, sedangkan H berada di tengahnya. Bentuk ini menyerupai Jamur dengan titik pusatnya. Selanjutnya pemain yang membentuk lingkaran bergerak berputar sambil menyanyi lagu Jamuran dengan syair sebagai berikut: 
Jamuran ya ge ge thok,

Jamur apa, ya ge ge thok,

Jamur gajih mbejijih sakara-ara,

Semprat-semprit jamur apa?

Sampai pada kalimat terakhir (Semprat-semprit jamur apa?), maka berhentilah pemain dengan gerak berputar tadi. Kemudian $\mathrm{H}$ harus menjawab pertanyaan tadi. Misalnya $\mathrm{H}$ menjawab Jamur let uwong, maka pemain yang membentuk lingkaran tadi saling mencari pasangan dan saling berangkulan (tidak harus dua orang, tiga orang boleh). Kemudian $\mathrm{H}$ mendatangi salah satu pasangan yang sedang berangkulan, misalnya A, B, C dan berusaha memisahkan salah satu di antara mereka. Misalnya B dapat dilepaskan dari rangkulannya, maka B berganti menjadi pemain dadi. B kemudian berada di tengah lingkaran, sedangkan $\mathrm{H}$ ikut kelompok pemain yang membentuk lingkaran. Namun demikian, jika $\mathrm{H}$ tidak dapat melepas salah satu pemain dari pasangan-pasangan tadi, maka $\mathrm{H}$ tetap menjadi pemain dadi. $\mathrm{H}$ akan berubah statusnya menjadi pemain mentas apabila dapat melepas salah satu pemain yang berangkul-rangkulan tadi.

Misalnya B menjadi pemain dadi, maka permainan diawali dari depan dengan menyanyikan lagu dari awal sambil berputar. Sampai pada kalimat terakhir (Sempratsemprit jamur apa?), B harus menjawab pertanyaan. Misalnya B menjawab Jamur Kendhi Borot, maka pemain yang membentuk lingkaran tadi cepat-cepat lari mencari tempat untuk buang air kecil. Bila ada yang belum bisa buang air kecil dan tertangkap oleh B, maka pemain tersebut menjadi pemain dadi. Demikian permainan jamuran diulang terus menerus sampai anak-anak mengakhiri permainan tersebut.

Adakalanya karena kekurangcekatan, maka seorang pemain menjadi pemain dadi terus menerus. Pemain demikian disebut dikungkung. Mengenai pertanyaan jamur apa? Jawabannya banyak sekali dan tergantung kepandaian si penjawab (pemain dadi). Jika pemain dadi dapat menjawab sesuatu jamur yang sangat sulit dipraktekkan dalam tingkah laku, maka kemungkinan untuk menangkap pemain menjadi lebih besar. Jawabanjawaban dari pertanyaan jamur apa?, misalnya:

Jamur kethek menek: para pemain supaya menirukan kera sedang memanjat, artinya mereka dapat memanjat pohon, bangku, kursi, dan lain-lain, yang penting tidak menginjak tanah. 
Jamur parut: para pemain supaya menyiapkan satu telapak kakinya untuk digaruk garuk oleh pemain dadi. Apabila yang digaruk merasa geli dan tertawa, maka pemain tersebut kalah, dan berubah status menjadi pemain dadi. Masih banyak lagi jenis jamur-jamur, tergantung kreasi anak-anak. Demikianlah permainan tradisional jamuran.

\section{B. Bermain dan Olah Pikir}

Jenis permainan tradisional dengan pola bermain dan oleh pikir banyak membutuhkan konsentrasi berpikir, ketenangan, kecerdikan, dan strategi. Permainan ini bersifat kompetitif perorangan, oleh karena itu tidak memerlukan arena yang luas. Permainan ini pada umumnya banyak digemari oleh anak laki-laki, tetapi tidak menutup kemunginan permainan ini dilakukan juga oleh perempuan. Contohnya Mul-mulan.

Mul-mulan berasal dari pengulangan kata mul dan mendapat akhiran an. Apabila setiap pemain dapat meletakan tiga uwong (orang-orangan) pada titik yang berurutan muncul ucapan mul. Permainan ini dapat dilakukan kapan saja, di mana saja, dan oleh siapa saja dari anak-anak sampai orang tua baik laki-laki maupun perempuan. Permainan ini biasanya dilakukan pada waktu senggang atau istirahat.

Permainan mul-mulan dilakukan dua anak, mereka bertanding satu sama lain. Perlengkapannya sangat murah dan mudah didapat. Landasan untuk bermain dapat karton, kertas, lantai ubin, lantai tanah, dan lainnya. Landasan tadi kemudian digambari bidang bujur sangkar. Kemudian diperlukan uwong yang dapat dibuat dari sobekan kertas, sobekan daun, kerikil, biji buah-buahan, dan sebagainya. Masing-masing pemain memiliki sembilan uwong dari bahan yang berbeda. Tujuan setiap pemain adalah memakan uwong dengan jalan meletakkan tiga buah uwong milik sendiri pada satu garis lurus.

Mengenai jalannya permainan sebagai berikut: permainan ini diawali kedua pemain membuat gambar dan membawa uwong dari bahan yang berbeda. Kemudian menentukan undian untuk menentukan siapa yang bermain lebih dulu. Misalnya, yang menang undian A, maka A mulai dengan meletakkan satu buah uwong pada satu titik yang diiginkan. Kemudian gantian B, ganti A, ganti B, dan seterusnya. Apabila A dapat meletakkan tiga buah uwong dalam satu garis lurus maka disebut mul dan berhak mengambil satu buah uwong milik B (dengan bebas). Begitu pula dengan B jika dapat 
mul boleh mengambil satu buah milik A (dengan bebas). Permainan ini dianggap selesai apabila uwong dari salah satu pemain itu habis. Seorang pemain dianggap menang apabila jumlah uwong lawan yang menjadi miliknya lebih banyak daripada milik lawannya. Demikian permainan ini dan dapat diulang sesuai dengan kesepakatan pemain tersebut.

\section{Bermain dan Adu Ketangkasan}

Jenis permainan bermain dan adu ketangkasan banyak mengandalkan ketahanan dan kekuatan fisik, membutuhkan alat permainan, dan tempat bermain yang relatif luas. Permainannya bersifat kompetitif, yang pada umumnya lebih banyak dimainkan oleh anak laki-laki. Pola permainan jenis ini pada umumnya berakhir dengan posisi pemain menang atau kalah serta ada sanksi hukuman bagi yang kalah, tergantung pada kesepakatan, misalnya yang kalah menggendong yang menang, yang kalah menyanyi, yang kalah dicablek, yang kalah menyerahkan permainannya, yang kalah mengejar yang menang, dan sebagainya.

Salah satu permainan yang sifatnya adu ketangkasan adalah Jeg-jegan. Permainan Jeg-jegan biasanya dilakukan pada sore hari. Pada saat liburan sekolah dapat dilakukan pada pagi dan siang atau jika anak-anak di sekolah dapat bermain pada waktu istirahat. Permainan Jeg-jegan adalah permainan kelompok dan setiap kelompok membutuhkan minimal tiga anak. Jadi untuk bermain minimal membutuhkan enam anak. Permainan ini dapat dilaksanakan oleh anak laki-laki maupun perempuan yang biasanya berumur antara 10 sampai dengan 15 tahun. Permainan ini memerlukan sebidang tanah luas (bisa halaman rumah, lapangan, sawah yang sedang tidak ditanami.

Jalannya permainan sebagai berikut. Pertama, para pemain menentukan anggota kelompok dengan cara undian. Jika terdapat enam anak (A, B, C, D, E, dan F) maka setiap kelompok beranggotakan tiga anak, misalnya kelompok I beranggotakan A, B, dan C sedangkan kelompok II beranggotakan D, E, dan F. Kedua, masing-masing kelompok membuat lingkaran di tanah bergaris tengah dua meter dan di titik pusat dibuat sebuah lubang kecil. Lubang ini disebut ngejegan. Ketiga, masing-masing kelompok membuat lubang kecil dan lingkaran serupa dengan jarak lima sampai enam meter dari lubang pertama di sebelah kanan agak ke depan dari ngejegan tadi, yang berfungsi sebagai tempat tawanan. Keempat, mereka menentukan batas wilayah permainan, misalnya 
hanya sebatas halaman rumah tempat bermaian. Kelima, menentukan peraturan yang harus dipatuhi oleh para pemain. Peraturan itu sebagai berikut:

1. Seorang pemain masing-masing kelompok hanya dapat mengejar seorang dari anggota kelompok lawan.

2. Jika seorang dikejar oleh lawan dan belum tertangkap, maka dia dapat kembali ke ngejegan dan dari sana dia boleh mengejar seorang lawan lain.

3. Begitu pula bagi seorang belum dapat menangkap lawan, dia harus kembali terlebih dulu ke ngejegannya dan kemudian dapat mengejar lawan yang lain.

4. Peserta yang berada di ngejegan tidak dapat dimatikan.

5. Bila seorang ditangkap oleh lawan, maka pemain tersebut menajdi mati dan harus masuk ke dalam penjara sebagai tawanan lawan.

6. Seorang yang dalam status mati dalam penjara dapat hidup kembali jika tangannya telah tersentuh oleh salah seorang teman kelompoknya.

7. Sesudah seorang dibebaskan dari penjara, maka dia harus kembali terlebih dahulu ke ngejegan-nya kemudian baru berhak mengejar lawannya.

8. Apabila ngejegan-nya sampai kosong, maka ngejegan tadi dapat diduduki oleh seorang lawan. Dengan demikian kelompok tersebut kalah. Bagi yang kalah mendapat sanksi sesui dengan kesepakatan

Untuk lebih jelasnya dapat disimak contoh jalannya permainan sebagai berikut: misalnya, kelompok I yang menang dalam undian, maka A keluar dari ngejegan untuk memancing agar dikejar leh kelompok II (misalnya yang mengejar D). Jika D dapat mengejar A dan dapat menyentuhnya, maka A mati dan ditawan di penjara tempat kelompok II. Seandainya A tidak dapat ditangkap oleh D, maka A dapat kembali ke ngejegan-nya sendiri. Jadi A orang pertama belum boleh mengejar lawan, baru setelah masuk ke ngejegan-nya, maka A berhak keluar dari ngejegan-nya untuk mengejar lawan. Sementara itu D yang sedang mengejar A boleh dikejar oleh B. Jika D tidak dapat menangkap A, maka dia harus kembali ke ngejegan-nya sendiri. Sementara B mengejar D, B dapat dikejar E. Demikian silih berganti, di mana setiap peserta hanya dapat mengejar seorang lawan dan hanya dapat dikejar oleh seorang lawan. Apabila dalam kejar-mengejar ini sampai sebuah ngejegan kosong tanpa penunggu seorang pun, maka pemain lawan boleh ngejegi (menduduki) ngejegan tersebut. Apabila ini terjadi maka 
kelompok pemilik ngejegan yang diduduki tadi mati, artinya kelompok tersebut kalah. Jika suatu kelompok kalah maka mereka menerima sanksi sesuai dengan kesepakatan. Dengan demikian permaian jeg-jegan itu sudah selesai dan dapat diulang kembali.

\section{Nilai-nilai yang Terkandung Dalam Permainan Jamuran, Mul-mulan, dan Jeg-jegan}

Secara umum permainan tradisional anak memiliki nilai-nilai luhur dan pesanpesan moral tertentu. Sierly sebagai penggagas lomba kaulinan budak di Spirit Camp mengatakan bahwa beberapa permainan tradisional tidak sekedar menghilangkan stres anak atau membuat fokus dalam pelajaran, tetapi juga mengajarkan nilai-nilai kebersamaan, kejujuran, tanggung jawab, sikap lapang dada (kalau kalah), dorongan berprestasi, dan taat pada aturan. Semua itu didapatkan kalau si pemain benar-benar menghayati, menikmati, dan mengerti makna dari permainan tersebut. Permainan tradisional lahir dari hasil kreativitas yang bersumber pada nilai-nilai kearifan lokal. Dalam bahasa Van Peursen, hal itu merupakan sebuah manifestasi kebudayaan dari setiap orang dan kelompok yang mengarah pada segala perbuatan manusia, seperti cara menghayati kehidupan. Begitu penting permainan tradisional, sehingga pemerintah melalui Dinas Kebudayaan memasukkannya sebagai salah satu bidang garapan. Hal ini merupakan upaya untuk mengkonservasi, mendata, merawat, dan melestarikan nilai-nilai budaya bangsa.

\section{Nilai-nilai dalam Permainan Tradisional Anak Jamuran.}

Setiap tingkah laku manusia tidak dapat bebas nilai, termasuk permainan tradisional anak. Nilai-nilai kehidupan sosial yang terkandung dalam permainan tradisional anak Jamuran adalah sebagai berikut:

a. Permainan Jamuran melahirkan nuansa suka cita. Dalam permainan tersebut jiwa anak terlihat secara penuh. Suasana ceria, senang yang dibangun senantiasa melahirkan dan menghasilkan kebersamaan yang menyenangkan. Inilah benih masyarakat yang "guyup rukun” itu dimulai. Permainan ini berguna untuk keceriaan bersama.

b. Permainan Jamuran dapat berlangsung secara wajar, karena mereka mengorganisir diri dengan membuat aturan main diantara anak-anak sendiri. Dalam konteks inilah anak-anak mulai belajar mematuhi aturan 
yang mereka buat sendiri yang disepakati bersama. Disatu sisi, anak belajar mematuhi aturan bermain secara fairplay, disisi lain, merekapun berlatih membuat aturan permainan itu sendiri. Sementara itu, apabila ada anak yang tidak mematuhi aturan permainan, dia akan mendapatkan sanksi sosial dari sesamanya. Dalam kerangka inilah, anak mulai belajar hidup bersama atau hidup bersosial. Namun demikian dipihak lain, apabila dia mau mengakui kesalahannya, teman yang lain pun bersedia menerimanya kembali. Suatu bentuk proses belajar mengampuni dan menerima kembali dari mereka yang telah mengakui kesalahannya (rekonsiliasi).

c. Permainan Jamuran tidak membedakan status sosial. Dalam permainan tradisional anak ini tidak membedakan status sosial artinya tidak membedakan dari latar belakang keluarga apapun dan semua anak dapat bermain, baik laki-laki maupun perempuan.

d. Permainan tradisional Jamuran, selain memiliki nilai keceriaan yang tinggi, permainan ini juga membantu anak berpikir strategis. Pada waktu pemain dadi harus menjawab pertanyaan Semprat semprit jamur apa, disinilah anak dilatih untuk berpikir strategis dan rasional, tidak hanya sekedar berkata-kata. Selain itu anak juga dilatih untuk melaksanakan apa yang menjadi keputusannya.

e. Permainan Jamuran sifatnya kelompok, hal ini sesuai dengan kehidupan di masyarakat yang selalu ada hubungan sosial, interaksi sosial antara satu dengan yang lain saling membutuhkan. Kebersamaan sangat dibutuhkan agar terjadi keharmonisan dalam hidup.

f. Selain hal-hal di atas permainan Jamuran juga mengandung pelajaran untuk mengekspresikan tentang lingkungan. Penyesuaian diri dengan lingkungan itu penting, apalagi masuk dalam lingkungan asing harus bisa menyesuaikan dengan lingkungan tersebut.

\section{Nilai-nilai Dalam Permainan Tradisional Mul-mulan}

Nilai-nilai kehidupan sosial yang terdapat dalam permainan tradisional $\mathrm{Mul}$ mulan adalah sebagai berikut: 
a. Dalam permainan Mul-mulan ini, anak dituntut kreatif sejak dalam proses pembuatannya yang harus berbaur dengan alam, karena media didapat dari lingkungan sekitar. Keterampilan anak senantiasa terasah, anak terkondisi membuat permainan dari berbagai bahan yang telah tersedia di sekitarnya. Dengan demikian, otot atau sensor motoriknya akan semakin terasah pula.

b. Dipihak yang lain, proses kreativitasnya merupakan tahap awal untuk mengasah daya cipta dan imajinasi anak memperoleh ruang pertumbuhannya.

c. Demikian pula saat memainkannya, selain dituntut kreatif juga harus memiliki strategi dan kejujuran. Hal ini menggambarkan bahwa dalam menjalankan hdup dan kehidupannya tidak dapat bertindak tanpa adanya pemikiran lebih dulu. Dalam bertindak tidak boleh "asal", karena jika mengambil langkah yang salah, maka akibatnya fatal. Oleh karena itu dalam bertindak harus hati-hati dan telah dipikirkan dengan segala kemungkinan akibatnya.

d. Melalui permainan ini anak dituntut untuk mematuhi aturan yang telah mereka sepakati. Kehidupan dalam masyarakat tidak bebas aturan, dapat hidup dengan baik jika dapat mematuhi aturan yang berlaku.

e. Melalui permainan ini anak-anak diajar untuk bersikap konsekuan dan lapang dada. Pada saat tindakannya keliru, maka akan menanggung akibatnya.

\section{Nilai-nilai Dalam Permainan Tradisional Anak Jeg-jegan}

Nilai-nilai yang terkandung dalam permainan tradisional Jeg-jegan adalah sebagai berikut:

a. Pemanfaatan media permainan Jeg-jegan, selalu tidak terlepas dari alam misalnya tanah lapang, halaman rumah atau halaman sekolah. Hal ini melahirkan interaksi antara anak dengan lingkungan sedemikian dekatnya. Kebersamaan dengan alam merupakan bagian terpenting dari proses pengenalan anak terhadap lingkungan hidupnya.

b. Hubungan yang sedemikian erat dengan lingkungan alam akan melahirkan 
penghayatan terhadap kenyataan hidup manusia. Alam menjadi sesuatu yang dihayati keberadaanya, tidak bisa terpisahkan dari kenyataan hidup manusia. Penghayatan inilah yang membentuk cara pandang serta penghayatan akan totalitas cara pendang mengenai hidup ini (kosmologi). Cara pandang inilah yang kemudian dikenal sebagai bagian dari sisi kerohanian manusia tradisional.

a. Melalui permainan tradisional Jeg-jegan anak-anak mulai mengenal model pendidikan partisipatoris. Artinya, anak memperoleh kesempatan berkembang sesuai dengan tahap-tahap pertumbuhan jiwanya.

b. Permainan tradisional Jeg-jegan, selain memiliki nilai keceriaan yang tinggi, permainan ini juga membantu anak berpikir strategis. Menolong temannya yang berada dalam cengkeraman lawan bermainnya dan juga membantu timnya memenangkan pertandingan, tentu membutuhkan kerja sama, kekompakan, dan kecerdasan berpikir, tanpa mencederai aturan permainan yang telah disepakati bersama. Sanksi sosial siap diterapkan atas diri anakanak yang berlaku tidak patut dalam permainan itu.

c. Permainan tradisional Jeg-jegan dimainkan secara berkelompok melatih kepekaan sosial anak-anak. Permainan berkelompok akan membangkitkan rasa saling membutuhkan antar-anak sehingga tumbuh saling menghargai. Interaksi anak-anak dalam permainan akan membangkitkan kemampuan anak untuk menilai mana yang baik dan tidak baik. Misalnya, ada anak yang bermain curang pasti teman-temannya akan memberi hukuman moral dengan tidak mengikutkan anak yang curang dalam permainan.

d. Permaian ini juga mengandung unsur kompetisi untuk meraih apa yang dicitacitakan yaitu adanya kemenangan. Adanya kompetisi ini memberi pelajaran pada anak bahwa dalam meraih suatu cita-cita membutuhkan usaha keras, banyak hal yang menjadi kendala.

e. Permainan tradisional juga mampu menumbuhkan nilai sportivitas. Misalnya, pada salah satu kelompok kalah, maka kelompok tersebut harus menanggung akibatnya sesuai dengan kesepakatan bersama yang dibuat bersama pada waktu permainan akan dimulai. 
Nilai-nilai yang ada dalam permainan tradisional di atas sangat berguna sebagai pelajaran bagi anak-anak untuk mempersiapkan diri dalam kehidupan sosial di masyarakat, maka di era globalisasi sekarang ini tetap relevan untuk dilestarikan.

\section{Karakteristik Permainan Tradisional Anak}

Permainan tradisional anak memiliki karakteristik tersendiri yang dapat membedakan dengan jenis permainan era globalisasi. Pertama, permainan tradisional menggunakan bahasa daerah, sehingga menunjukkan ciri budaya lokal yang kuat. Bahkan penggunaan bahasa daerah ini juga tidak mungkin diganti oleh bahasa lain karena dapat menghilangkan makna simbolis yang terkandung dalam permainan tersebut. Dengan demikian pelestarian permainan tradisional anak ini tidak berlebihan jika yang berkewajiban mengajarkan adalah lingkungan setempat, baik orang tua, sekolah, dan masyarakat. Kedua, Permainan tradisional anak-anak biasanya dipelajari ketika individu masih anak-anak. Apa yang ada dalam permainan tersebut dapat mudah diserap dengan cepat dan kemudian mengendap dengan kuat dalam bawah sadar seseorang individu. Apa yang ada dalam bawah sadar ini kadang-kadang muncul, dan membangkitkan kehidupan seseorang untuk kembali ke masa anak-anak. Ketiga, permainan itu cenderung menggunakan atau memanfaatkan alat atau fasilitas di lingkungan kita tanpa harus membeli. Keempat, permainan tradisional memerlukan adanya daya imajinasi dan kreativitas tinggi. Dalam hal ini, si pemain harus bisa menafsirkan, mengkhayalkan, dan memanfaatkan beberapa benda yang akan digunakan dalam bermain sesuai dengan yang diinginkan. Kelima, permainan tradisional dominan melibatkan pemain yang relatif banyak atau berorientasi komunal. Tidak mengherankan, jika dapat dilihat, hampir setiap permainan tradisional anak begitu banyak anggotanya. Sebab, selain mendahulukan faktor kegembiraan bersama, permainan ini juga mempunyai maksud lebih pada pendalaman kemampuan interaksi antar pemain (potensi interpersonal).

\section{Pelestarian Permainan Tradisional Anak Sebagai Unsur Budaya}

Dalam Ilmu Antropologi, kata "kebudayaan" sama artinya dengan kata "budaya" (singkatannya) yaitu keseluruhan sistem gagasan, tindakan, dan hasil karya manusia dalam rangka kehidupan masyarakat yang dijadikan milik diri manusia dengan belajar 
(Koentjaraningrat, 1979). Memperhatikan pengertian budaya tersebut berarti bahwa hampir seluruh tindakan manusia adalah budaya. Sangat sedikit tindakan manusia dalam kehidupan masyarakat yang tidak perlu dibiasakan dengan cara belajar yaitu hanya beberapa gerakan reflex atau tindakan yang sedang membabi buta. Permainan tradisional anak merupakan salah satu bentuk wujud budaya dimana era globalisasia ini budaya bersifat sangat dinamis.

Dengan adanya proses globalisasi yang akan bertambah kuat di masa-masa yang akan datang, permainan tradisional anak dapat dipandang sebagai salah satu aset budaya yang dapat membantu melestarikan jati diri seorang individu, sebuah komunitas, sebuah suku bangsa ataupun suatu bangsa (Heddy Shri Ahimsa-Putra, 2008). Melihat pernyataan tersebut, maka permainan tradisional anak sebagai unsur budaya tetap dianggap penting yang memiliki fungsi positif bagi kehidupan seorang individu ataupun kehidupan sebuah komunitas. Dengan demikian tidaklah berlebihan jika permainan tradisional anak dianggap sebagai sebuah warisan yang perlu dilestarikan keberadaannya.

Pelestarian permainan tradisional anak dapat dilakukan dengan dua macam bentuk, yaitu:

1. Dalam bentuk statis yaitu dengan cara-cara sebagai berikut:

a. Melakukan identifikasi yaitu untuk mengetahui unsur-unsur budaya yang masih ada dan mengelompokkannya ke dalam beberapa kategori.

b. Melakukan pendokumentasian baik melalui film, video, foto, dan tulisan. Dengan cara ini permainan tradisonal anak yang mungkin tidak akan pernah hadir lagi di tengah kehidupan masyarakat, masih akan dapat diketahui oleh generasi yang akan datang dan dapat ditampilkan kembali jika dikehendaki.

2. Dalam bentuk dinamis yaitu dengan mengajarkan kepada anak-anak bagaimana permainan tradisional itu yang belum mereka kenal dapat dimainkan. Mengajarkan permainan tradisional kepada anak-anak dapat dilakukan melalui jalur pendidikan, yaitu jalur informal (keluarga), formal (sekolah), dan nonformal (masyarakat).

Pengajaran permainan tradisional anak melalui jalur informal dibutuhkan kepedulian, pengorbanan dari orang tua dan hal ini dapat dilakukan pada waktu-waktu istirahat. 
Dengan adanya kepedulian orang tua, maka anak-anak akan dapat merasakan dan menghayati permainan tradisional tersebut.

Permainan tradisional anak melalui jalur pendidikan formal dapat dimasukkan dalam kurikulum khususnya sebagai mata pelajaran muatan lokal. Dengan masuknya permainan tradisional anak dalam muatan lokal berarti akan melestarikan budaya setempat baik dengan bahasa lokal, peralatan, dan lingkungan sehingga identitas daerah tetap terjaga kelestariannya. Dalam hal ini seorang guru Sekolah Dasar (SD) mempunyai peran penting untuk mengajarkannya kepada anak didiknya. Anak seusia SD masih berpikir secara konkret, dengan anak bermain artinya mereka mengalami sendiri, sehingga guru mudah menanamkan nilai-nilai yang ada dalam permainan tersebut yang sangat berguna dalam kehidupan sosial.

Pengajaran permainan tradisional anak melalui jalur nonformal dibutuhkan kepedulian dari masyarakat. Hal ini juga dapat dilakukan pada waktu-waktu senggang, misalnya hari libur. Selain itu dapat dilakukan pada waktu peringatan harihari besar nasional, misalnya hari pendidikan nasional, hari Kartini, dan hari ulang tahun kemerdekaan bangsa Indonesia. Selain itu di dalam masyarakat bisa melestarikan permainan tradisional anak dengan cara mendirikan sanggar atau kelompok permainan tradisional. Cara yang lain dengan mengadakan lomba sebagai kelanjutan pengajaran sebelumnya sebagai bukti bahwa suatu permainan tertentu telah dikuasainya.

Pelestarian dengan cara-cara tersebut akan membuat anak-anak sebagai generasi penerus bangsa lebih dapat merasakan dan menghayati permainan yang akhirnya diharapkan dapat menerapkan dalam kehidupan sosialnya dalam masyarakat.

\section{Manfaat Pelestarian Permainan Tradisioanl Anak}

Memperhatikan permainan tradisional anak mengandung nilai-nilai kehidupan sosial, maka di era globalisasi ini tetap relevan untuk dilestarikan keberadaannya, karena permainan tersebut merupakan sarana sosialisasi yang efektif terhadap nilai-nilai luhur yang dipandang penting oleh masyarakat. Nilai-nilai kehidupan sosial tersebut diinginkan dapat menjadi pedoman hidup, pedoman berperilaku setiap individu dalam masyarakat sehari-hari. Jika permainan tradisional anak hilang berarti hilang pula sarana sosialisasi 
niali-nilai yang efektif dan akhirnya akan mempengaruhi kelestarian nilai-nilai yang dipandang penting dalam kehidupan bermasyarakat.

Selain sebagai sarana sosialisasi nilai-nilai yang dianggap penting dalam masyarakat, permainan tradisional anak juga sebagai arena sosial. Hal ini sejalan dengan sifat manusia sebagai makhluk sosial yang hidup bermasyarakat. Di dalam masyarakat inilah tempat untuk mempraktekkan kehidupan bersama untuk mencapai tujuan tertentu.

Akhirnya, permainan tradisional dapat dijadikan sebagai hiburan gratis yang dapat menjadi pelepas rasa penat, sedih, marah, dan sebagainya. Setelah mengalami kegembiraan, anak-anak dapat kembali dalam kehidupan sehari-hari dengan semangat baru untuk menjalankan peran masing-masing. Dengan demikian permainan tradisional sebagai arena untuk menanamkan semangat sosial dan komunal baru kepada warga masyarakat.

\section{Penutup}

Permainan tradisional anak sering dipandang sebelah mata oleh masyarakat khususnya orang tua. Mereka mengaggap permainan tradisional hanya sebagai aktivitas bercanda buang-buang waktu dan energi saja. Banyak orang tua di era globalisasi ini tidak mengizinkan anaknya untuk melakukan permainan bergabung dengan anak-anak dari berbagai latar belakang yang berbeda itu. Terkadang, para orang tua juga merasa gengsi jika anak-anaknya bermain di tanah lapang, di tempat yang kotor penuh debu dan rumput. Orang tua lebih memilih permainan yang modern dan canggih yang bisa dilakukan sendiri, dengan alasan bisa melakukan dengan puas. Bahkan oleh banyak orang, permainan tradisional anak dicurigai sebagai penyebab merosotnya nilai pelajaran yang diterima dari sekolah.

Pada hal jika diamati secara sungguh-sungguh, banyak manfaat yang dapat diambil sebagai pelajaran dari permainan tradisional anak. Lewat permainan tradisional anak, akar demokrasi pun bisa tertanam dan tumbuh dalam jiwa anak-anak saat dewasa kelak. Sekali lagi, banyak hal yang dapat diambil sebagai pelajaran dalam permainan tradisional anak itu. Oleh karena itu, tidak berlebihan jika permainan tradisional dimasukkan dalam kurikulum, sepanjang nilai-nilai yang ada di belakang permainan itu berguna untuk bekal hidup di masyarakat. Dengan demikian mengajarkan permainan 
tradisional kepada anak merupakan langkah positif yang harus dilestarikan baik oleh keluarga, sekolah, maupun oleh masyarakat.

\section{Daftar Pustaka}

Dani Wardani. 2007. Potret Permainan Tradisional di Indonesia. Kompas, Kamis 06 Desember 2007.

Dharmamulya, Sukirman. 2008. Permainan Tradisional Jawa. Yogyakarta: Kepel Press.

Heddy Shri Ahimsa-Putra. 2008. "Permainan Tradisional Anak-anak di Jawa dan Tantangan Era Kesejagadan”, dalam Permainan Tradisional Jawa. Yogyakarta: Kepel Press.

Husein Achmad, 1982. Konsep-Konsep Ilmu Pengetahuan Sosial. Yogyakarta: FKIS IKIP.

http://beta.pikiran-rakyat.com/index.php?mib=beritadetail\&id=1206

Koentjaraningrat. 1979. Pengantar Ilmu Antropologi. Jakarta: Bumi Aksara.

Kosasih Djahiri. 1980. Ilmu Pengetahuan Sosial. Bandung: LPP-IPS IKIP.

Mulyana, Rohmat. 2004. Pendidikan Nilai. Bandung: Alfabeta.

Rukiyati, dkk. 2008. Pendidikan Pancasila. Buku Pegangan Kuliah. Yogyakarta: UPT MKU UNY.

)* Mujinem Dosen Jurusan PPSD FIP UNY di Yogyakarta 